\title{
Estimation of Amino Acid Quality of Food for Benthic Invertebrates and Fish on the Basis of Comparative Study of Amino Acids of Periphyton and Zoobenthos of the Yenisey River
}

\author{
Anzhelika A. Kolmakova ${ }^{a *}$, Michail I. Gladyshevev, \\ Galina S. Kalachova ${ }^{a}$, Elena S. Kravchuk ${ }^{a}$, \\ Elena A. Ivanova ${ }^{\mathrm{a}, \mathrm{b}}$ and Nadezhda N. Sushchik ${ }^{\mathrm{a}, \mathrm{b}}$ \\ anstitute of Biophysics of SB RAS \\ 50/50 Akademgorodok, Krasnoyarsk, 660036, Russia \\ ${ }^{b}$ Siberian Federal University \\ 79 Svobodny, Krasnoyarsk, 660041, Russia
}

Received 04.11.2014, received in revised form 19.12.2014, accepted 14.01.2015

\begin{abstract}
Amino acid (AA) composition of periphyton and zoobenthos of the shallow part in the middle section of the Yenisei River on the basis of monthly sampling during 2007-2010 was studied. Seasonal variations in the amino acid profile of periphyton were detected, which may be related to seasonal succession of microalgae species. Pronounced differences in AA compositions of different species of riverine zoobenthos were found. The imbalance in amino acid profile of macrozoobenthos compared to its food, that is periphyton, in respect of two essential amino acids - lysine and histidine, was shown. The nutritional value of Gammarus - the recent invader in the studied section of the Yenisei River was evaluated and compared to that of indigenous taxa-trichopteran and chironomid larvae.
\end{abstract}

Keywords: amino acids, periphyton, zoobenthos, fish, food quality, the Yenisey River.

(c) Siberian Federal University. All rights reserved

* Corresponding author E-mail address: angelika_@inbox.ru 


\title{
Оценка аминокислотного качества пищи
}

\section{бентосных беспозвоночных и рыб}

на основе сравнительного изучения

аминокислот перифитона и зообентоса р. Енисей

\author{
А.А. Колмакова ${ }^{\text {a }, ~ М . И . ~ Г л а д ы ш е в ~}{ }^{\text {a, }}$, Г.С. Калачева ${ }^{a}$, \\ Е.С. Кравчук ${ }^{a}$, Е.А. Иванова ${ }^{a, \tilde{\sigma}}$, Н.Н. Сущика ${ }^{\mathrm{a}, \overline{6}}$ \\ ${ }^{a}$ Институт биофизики СО РАН \\ Россия, 660036, Красноярск, Академгородок, 50/50 \\ ${ }^{6}$ Сибирский федеральный университет \\ Россия, 660041, Красноярск, пр. Свободный, 79
}

На основе ежемесячного пробоотбора 2007-2010 г2. изучен аминокислотный состав перифитона и макрозообентоса на литоральной станиии в среднем течении р. Енисей. Выявлены сезонные колебания профиля аминокислот в перифитоне, которые могут быть связаны с сезонной сукиессией видов микроводорослей. Обнаружены достоверные различия аминокислотного состава у различных видов речного зообентоса. Показана несбалансированность аминокислотного профиля макрозообентоса в сравнении с его пищей - перифитоном - в отношении двух незаменимых аминокислот - лизина и гистидина. Оченена питательная ценность для рыб недавно вселившегося в реку Енисей гаммаруса, относительно вытесняемых им эндогенных видов - личинок ручейников и хирономид.

Ключевые слова: аминокислоты, перифитон, зообентос, рыбы, качество пищи, река Енисей.

\section{Введение}

Как известно, элементный и биохимический составы растений и животных значительно различаются. Это приводит к лимитированию процесса переноса вещества и энергии в экосистемах на стадии взаимодействия пары продуцент - первичный консумент.

Традиционно основными факторами, ограничивающими рост первичных консументов при высокой биомассе продуцентов, считаются стехиометрическое соотношение C:N:P (Giani, 1991; Stelzer and Lamberti, 2002; Acharya et al., 2004; Cross et al., 2005; Ventura et al., 2008), содержание незаменимых полиненасыщенных жирных кислот (ПНЖК) семейства $\omega 3$ (Brett and Muller-Navarra, 1997; Boersma et al., 2001), а также стеринов (MartinCreuzburg et al., 2005) в продуцентах.

Вместе с тем продуценты обладают и другими специфическими биохимическими особенностями, такими как аминокислотный состав, которому до настоящего времени не уделялось должного внимания.

Отсутствие интереса к изучению аминокислот (АК) при исследовании качества пищи гидробионтов вызвано устойчивым представлением о постоянстве состава АК микроводорослей в отличие от состава ПНЖК (Ahlgren et al., 1992; Brown et al., 1997; Muller-Navarra, 2008). Этим объясняется столь незначительное количество накопленных к настоящему 
времени данных об аминокислотном составе микроводорослей.

Тем не менее стехиометрическая теория, распространенная на биогенные элементы, предсказывает, что содержание АК в первичных продуцентах также может быть лимитирующим фактором для консументов (Anderson et al., 2004). К тому же существует ряд работ, указывающих на влияние содержания АК в пище на размножение морских копепод (Guisande et al., 2000; Helland et al., 2003). Более того, было показано, что некоторые незаменимые аминокислоты (аргинин (Arg) и гистидин (His)) вовлечены в запуск механизма перехода между типами размножения у дафнии (Koch et al., 2011). Поскольку профиль АК природных источников пищи подвержен сезонным измениям (Kalacheva et al., 2004), развитие пресноводных первичных консументов может быть лимитировано не только элементным составом или составом ПНЖК, но также составом незаменимых АК в пище.

Большинство работ, направленных на изучение состава АК водных продуцентов относительно потребностей первичных консументов, посвящено пелагическим экосистемам, т.е. фито- и зоопланктону. Однако в реках с высокой скоростью течения часто основными производителями первичной продукции являются бентосные (перифитонные) микроводоросли (Fuller and Bucher, 1991; Uehlenger, 2006; Kolmakov et al., 2008). К сожалению, данные о составе АК перифитонных микроводорослей в основном ограничиваются анализом лабораторных культур (Steinman and McIntire, 1987; Khatoon et al., 2009). Крайне мало известно о составе АК микроводорослей природных перифитонных сообществ (Ylla et al., 2011). Особенно это касается бентосных перифитонных водорослей больших рек.

Исследование биохимического состава и пищевой ценности речного перифитона необходимо, поскольку в реках перифитон зачастую играет важную роль как источник пищи для бентосных беспозвоночных на ранней стадии развития (Power and Matthews, 1983; Hill and Knight, 1987; Muller-Feuga, 2000; Sushchik et al., 2003). В свою очередь, речной зообентос является кормом для многих видов рыб (Power and Matthews, 1983; Ronnestad et al., 1999; Conceição et al., 2003). Несбалансированность АК состава пищи (перифитона) для первичных консументов (макрозообентоса) негативно отражается на многих физиологических процессах, включая рост, иммунитет и размножение водных беспозвоночных, что, в свою очередь, приводит к ухудшению кормовой базы рыб (Kleppel et al., 1998; Conceição et al., 2003; Aragao et al., 2004; Helland et al., 2010). Рыбам для нормального развития и жизнедеятельности требуется десять незаменимых аминокислот (НАК). Среди них особая роль отводится лизину (Lys), поскольку эта НАК обнаружена в наивысшей концентрации в телах рыб (Wilson and Cowey, 1985; Wilson and Poe, 1985; Kim and Lall, 2000). Кроме важной роли в синтезе протеина лизин совместно с метионином служит предшественником карнитина, который вовлечен в процесс транспорта длинноцепочечных жирных кислот в митохондрии для бета-окисления (Walton et al., 1984). Лизин наиболее часто вызывает лимитирование роста животных по сравнению с прочими незаменимыми аминокислотами, что связано с низким содержанием этой аминокислоты в растительном белке (Fox et al., 1995; Forster and Ogata, 1998). Поэтому необходимо выявить возможные различия в АК составах первого и второго звеньев трофической цепи рек, перифитона и макрозообентоса. Также необходимо оценить возможное влияние изменения состава зообентосного сообщества p. Енисей, произошедшего в результате инвазии гаммаруса из оз. Байкал (Gladyshev and 
Moskvicheva, 2002) и вытеснения доминирующих на этом участке до инвазии видов - личинок хирономид и ручейников, на его пищевую ценность в отношении аминокислот для потенциальных потребителей - рыб.

Целью нашей работы было получить ответы на следующие вопросы: 1. Существует ли лимитирование первичных консументов (бентосных беспозвоночных) АК составом продуцентов (перифитона)? 2. Влияет ли инвазия гаммаруса на пищевую ценность для рыб всего зообентоса?

Для этого необходимо: 1) определить АК состав природных популяций первого и второго звеньев трофической цепи, перифитона и макрозообентоса в р. Енисей; 2) выяснить, является ли АК профиль перифитона неизменным в течение сезонной сукцессии видов микроводорослей; 3) проверить, существуют ли различия в АК составах у различных видов речного зообентоса; 4) сравнить пищевую ценность для рыб инвазивного гаммаруса с пищевой ценностью эндемических видов (личинки хирономид и ручейников), доминировавших на изучаемом участке p. Енисей до инвазии.

\section{Материалы и методы}

\section{Район работ}

Исследование проводилось на одной из крупнейших рек России - p. Енисей. Площадь её водосбора составляет 2650000 км², а среднегодовой сток воды - 600 км³ $^{3}$ Подробная информация об экологических особенностях р. Енисей дана в работе (Telang et al. 1991). Основными гидрологическими особенностями исследуемой реки является низкая перемешиваемость и низкая соленость (100 мг/л). Уровень насыщения растворенным кислородом около $100 \%$, содержание органического углерода изменяется от 7 до 10 мг/л.
Место отбора проб находилось в 30 км ниже по течению от плотины Красноярской ГЭС (построена в 1972 г.) около г. Красноярска. В этом районе дно каменистое, скорость течения до 2 м/с. Зимой ледяной покров в районе отбора проб отсутствует вследствие перемешивания с нижними слоями воды, поступающими из водохранилища. Температура воды колебалась в пределах $5-10{ }^{\circ} \mathrm{C}$ весной-летом и $0-5{ }^{\circ} \mathrm{C}$ осенью-зимой. Детальная гидроэкологическая информация о месте отбора проб собрана в работах (Sushchik et al., 2006; Kolmakov et al., 2008; Anishchenko et al., 2010; Kalachova et al., 2011; Gladyshev et al., 2012).

В перифитоне весной и в начале лета доминировали зеленые водоросли рода Ulothrix. Летом в перифитоне преобладали представители нескольких родов диатомовых микроводорослей - Gomphonema, Didymosphaenia, Fragilaria, Aulacoseira и Cymbella, - которые сменяли друг друга. Поздней осенью и зимой доминирующими становились цианобактерии родов Chamaesiphon, Oscillatoria и Phormidium (Kolmakov et al., 2008; Anishchenko et al., 2010; Sushchik et al., 2010).

Биомасса зообентоса варьировала и до-

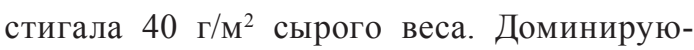
щим видом был Eulimnogammarus viridis Dybowsky (Gladyshev and Moskvicheva, 2002; Sushchik et al., 2006). Субдоминантами были личинки Trichoptera, Apatania crymophila McLachlan и личинки Chironomidae, среди которых преобладали Prodiamesa olivacea Meiden, Pseudodiamesa branickii Nowicki, Cricotopus algarum Kieffer, Orthocladius rhyacobius Kieffer и некоторые др. Личинки Ephemeroptera были представлены Ephemerella setigera Bajkova, Ephemerella ignita Poda и Ephemerella aurivillii Bgtss (Sushchik et al., 2006; Sushchik et al., 2007; Kalachova et al., 2011). 
Отбор проб

Пробы отбирали ежемесячно с февраля 2007 по апрель 2010 г. в прибрежной зоне на глубине 0.5 м. Пробы зообентоса собирали при помощи самплера типа Surber (рамка $40 \times 35$ см, размер ячеи сети 0.25 мм) и доставляли в лабораторию в течение часа после сбоpa.

Пробы перифитона собирали с поверхности каменистого субстрата, состоявшего преимущественно из булыжника (диаметром 10-15 см) и гальки (диаметром 2-10 см). Из установленной на дне рамки размером $10 \times 10$ см отбирались булыжник и галька, с которых щетками соскабливали все обрастания в определенный объем воды. В лаборатории пробу перемешивали путем встряхивания в течение нескольких минут и немедленно делили на части для микроскопического исследования и проведения элементного и аминокислотного анализа.

\section{Подготовка проб и химический анализ}

В лаборатории организмы зообентоса отбирали из нефиксированных проб, определяли и распределяли на четыре группы видов: гаммарусы (Gammaridea), личинки ручейников (Trichoptera), личинки хирономид (Chironomidae) и личинки поденок (Ephemeroptera). Организмы зообентоса каждой группы объединяли для определения биомассы. Сразу после разделения на группы живые организмы зообентоса помещали в стаканы с фильтрованной водой для очищения их кишечников на 24 ч. Затем с поверхности тел животных удаляли лишнюю влагу с помощью фильтровальной бумаги; тела взвешивали и хранили до анализа в плотно закрытой стеклянной пробирке в холодильнике при минус $20^{\circ} \mathrm{C}$.

Известно, что перифитон является сложным сообществом, в которое входят водо- росли, бактерии и беспозвоночные. Однако с помощью микроскопического анализа было установлено, что перифитон р. Енисей преимущественно состоял из эукариотических и прокариотических микроводорослей, тогда как бактерии и мелкие инфузории занимали лишь незначительную долю (7-12 \% от биомассы). Таким образом, в данной работе мы рассматривали его как фитоперифитон.

Определение и подсчет микроводорослей проводили в камере Фукса-Розенталя (объем 0.0032 мл) под световым микроскопом с увеличением в 400 раз. Биомассу определяли счетно-объемным методом (Hillebrand et al. 1999), размеры клеток измеряли при помощи окуляр-микрометра.

Для биохимического анализа аликвоты взвеси фитоперифитона центрифугировали при 6000 оборотах 12 мин, осадок собирали на фильтры, покрытые слоем $\mathrm{BaSO}_{4}$ для облегчения удаления осадка. Фильтры с осадком сушили в десикаторе в течение 24 ч и затем хранили при минус $20{ }^{\circ} \mathrm{C}$ до анализа. Детально AK-анализ описан в работе Kalachova et al. (2004). Сухие измельченные пробы микроводорослей или организмы зообентоса помещали в тонкостенные стеклянные ампулы (12×120 мм) и добавляли 20 мл $6 \mathrm{~N} \mathrm{HCl}$. Поскольку в отдельные даты масса выловленного зообентоса была меньше, чем требовалась для стандартного гидролиза, пробы зообентоса с массой менее чем 100 мг сырого веса помещали в ампулы меньшего размера (10×60 мм). Количество соляной кислоты для гидролиза проб зообентоса зависело от массы пробы и изменялось от 3 до 30 мл. Гидролиз проводили 22 ч при $110^{\circ} \mathrm{C}$. Затем пробы остужали, фильтровали и переносили в фарфоровые чашки для выпаривания. Выпаривание кислоты проводили на кипящей водяной бане. Сухой остаток, содержащий АК, растворяли в буферном растворе A0992-7 (Knauer, Германия). Пробы очищали перед анализом, 
пропуская их через картриджи Diapak C1 (BioChimMak ST) для отделения от гидрофобных субстанций, способных засорить колонку и помешать разделению. Для определения АК использовали высокоэффективный жидкостный хроматограф A0326V2 (Knauer, Германия), снабженный колонкой 125 мм $\times 3$ мм (А099213v1, Knauer, Германия), нингидриновым реактором и UV-детектором 2500. Количество каждой АК (мг/г) высчитывали сравнением площадей пиков АК исследуемых образцов с таковыми стандартного калибровочного раствора (Pickering, США). Этим методом были определены шестнадцать АК, среди них незаменимые аминокислоты (НАK): лизин (Lys), гистидин (His), аргинин (Arg), треонин (Thr), валин (Val), метионин (Met), изолейцин (Ile), лейцин (Leu), фенилаланин (Phe) (Lehninger et al., 1993; Guisande et al., 1999; Aragao et al., 2004; Peres and Oliva-Teles, 2006) и заменимые, аспарагиновая кислота (Asp), серин (Ser), глютаминовая кислота (Glu), глицин (Gly), аланин (Ala), цистин (Cуs), тирозин (Tyr). В пробах перифитона и зообентоса было определено содержание общего органического углерода на элементном анализаторе Flash EA 1112 NC Soil/MAS 200 (Neolab LLC, CШA) (Gladyshev et al. 2007).

\section{Статистический анализ}

Были проведены мультивариантный дискриминантный анализ (MDA), канонический корреляционный анализ (ССА), $t$-тест Стьюдента, однофакторный дисперсионный анализ (ANOVA) c LSD post-hoc тестом Фишера (Campbell, 1967; Jeffers, 1981). Расчеты выполнены с использованием пакета STATISTICA, версия 9.0 (StatSoft, Inc.).

\section{Результаты}

В перифитоне и в зообентосе р. Енисей были определены 16 АК, среди которых было
9 незаменимых AK: Lys, His, Arg, Thr, Val, Met, Ile, Leu, Phe (табл. 1). Большинство AK имели нормальное распределение в пробах, за исключением Thr в зообентосе, Asp в перифитоне, Суs и Met как в перифитоне, так и в зообентосе (табл. 1). Уровни Asp, Thr, Ser, Gly, Ala, Val, Cys, Met, Ile и Leu в перифитоне были достоверно выше, чем в зообентосе. Напротив, уровни Glu, Tyr, His и Lys в зообентосе были выше, чем в перифитоне. Уровни Phe и $\mathrm{Arg}$ в перифитоне и зообентосе достоверно не различались (табл. 1).

Биомасса перифитона, приходящегося на единицу площади литорали, в среднем в 6 раз выше, чем общая биомасса зообентоса (табл. 2). Пул органического углерода, содержащийся в перифитоне, приходящемся на единицу площади литорали, был только в 2 раза выше, чем в общей биомассе зообентоса (табл. 2). Пул АК перифитона в среднем в 1.7 раза выше, чем суммарный пул АК доминирующих групп зообентоса (табл. 2). Общее содержание АК на единицу сухого веса в личинках ручейника было существенно выше, чем в гаммарусах и личинках хирономид согласно $t$-тесту Стьюдента: $t=5.49, p<0.001$ при степенях свободы d.f. $=52$, и $t=3.64$, $p<0.001$, d.f. $=37$ соответственно (табл. 2). Личинки хирономид содержали больше АК в пересчете на сухой вес, чем гаммарусы: $t=2.44, p<0.05$, d.f. $=47$ (табл. 2). Личинки ручейника содержали существенно больше АК по отношению к единице органического углерода, чем гаммарусы и личинки хирономид (табл. 2). Все виды зообентоса содержали существенно больше АК по отношению к единице органического углерода, чем перифитон (табл. 2).

Поскольку нельзя разделить виды микроводорослей в перифитоне, для изучения возможных различий в АК составе перифитонных видов мы рассматривали сезонные 
Таблица 1. Процентное содержание (среднее $\pm \mathrm{SE}$ ) аминокислот в перифитоне $(\mathrm{n}=34)$ и зообентосе (Gammaridea, Trichoptera, Chironomidae и Ephemeroptera n =75) в р. Енисей в окрестностях г. Красноярска, февраль 2007 - апрель 2010: $\mathrm{D}_{\mathrm{K}-\mathrm{s}}$ - тест Колмогорова-Смирнова, $t$ - тест Стьюдента отклонений от среднего, $p$ - достоверность различий; звездочки указывают на ненормальное распределение в соответствии с $\mathrm{D}_{\mathrm{K}-\mathrm{s}}$, следовательно, использовался непараметрический U-тест Манна-Уитни вместо $t$ - теста. НАК выделены жирным шрифтом

\begin{tabular}{lcccccccccc}
\hline & \multicolumn{2}{c}{ перифитон } & D $\mathrm{D}$-s & \multicolumn{2}{c}{ зообентос } & $\mathrm{D}_{\text {к-s }}$ & $t$ или U & $p$ \\
\hline Leu & 8.30 & \pm & 0.11 & 0.150 & 7.82 & \pm & 0.10 & 0.142 & 2.89 & 0.004669 \\
Arg & 6.66 & \pm & 0.62 & 0.128 & 7.28 & \pm & 0.50 & 0.095 & 0.72 & 0.471170 \\
Val & 6.55 & \pm & 0.11 & 0.147 & 5.82 & \pm & 0.08 & 0.080 & 5.02 & 0.000002 \\
Thr & 6.54 & \pm & 0.11 & 0.191 & 5.95 & \pm & 0.11 & $0.165^{*}$ & $692.0 *$ & 0.000061 \\
Lys & 6.32 & \pm & 0.09 & 0.094 & 7.38 & \pm & 0.13 & 0.076 & 5.29 & 0.000001 \\
Phe & 5.19 & \pm & 0.08 & 0.169 & 5.19 & \pm & 0.09 & 0.111 & 0.01 & 0.987584 \\
Ile & 5.15 & \pm & 0.09 & 0.159 & 4.78 & \pm & 0.05 & 0.067 & 3.84 & 0.000206 \\
His & 2.12 & \pm & 0.06 & 0.100 & 3.36 & \pm & 0.06 & 0.052 & 13.48 & 0.000000 \\
Met & 0.94 & \pm & 0.12 & $0.275^{*}$ & 0.36 & \pm & 0.13 & $0.371^{*}$ & $426.5 *$ & 0.000000 \\
Glu & 13.32 & \pm & 0.21 & 0.113 & 13.98 & \pm & 0.17 & 0.091 & 2.22 & 0.028504 \\
Asp & 12.65 & \pm & 0.22 & $0.291^{*}$ & 11.25 & \pm & 0.17 & 0.135 & $543.0 *$ & 0.000001 \\
Ala & 8.12 & \pm & 0.17 & 0.063 & 6.82 & \pm & 0.17 & 0.127 & 4.78 & 0.000006 \\
Gly & 7.10 & \pm & 0.16 & 0.120 & 5.48 & \pm & 0.07 & 0.073 & 10.61 & 0.000000 \\
Ser & 6.14 & \pm & 0.13 & 0.184 & 5.08 & \pm & 0.07 & 0.087 & 7.56 & 0.000000 \\
Tyr & 3.95 & \pm & 0.19 & 0.112 & 9.33 & \pm & 0.24 & 0.077 & 13.97 & 0.000000 \\
Cys & 0.95 & \pm & 0.15 & $0.286^{*}$ & 0.14 & \pm & 0.03 & $0.428^{*}$ & $202.0 *$ & 0.000000 \\
\hline & & & & & & & & & &
\end{tabular}

Таблица 2. Количественные характеристики (среднее $\pm \mathrm{SE}$ ) перифитона и таксономических групп зообентоса: биомасса (Б), органический углерод (С), сумма аминокислот (АК), сумма АК на единицу сухой массы и на единицу массы органического углерода в р. Енисей в окрестностях г. Красноярска, февраль 2007 - апрель 2010

\begin{tabular}{|c|c|c|c|c|c|c|c|c|c|c|c|c|}
\hline \multirow[b]{2}{*}{ Б г $/ \mathrm{M}^{2}$} & \multicolumn{3}{|c|}{ перифитон } & \multicolumn{3}{|c|}{ Gammaridea } & \multicolumn{3}{|c|}{ Trichoptera } & \multicolumn{3}{|c|}{ Chironomidae } \\
\hline & 123.6 & \pm & 71.2 & 17.5 & \pm & 3.1 & 1.1 & \pm & 0.4 & 1.3 & \pm & 0.6 \\
\hline $\mathrm{C} \Gamma / \mathrm{M}^{2}$ & 6.0 & \pm & 1.3 & 2.1 & \pm & 0.4 & 0.5 & \pm & 0.2 & 0.3 & \pm & 0.3 \\
\hline $\mathrm{AK} \Gamma / \mathrm{M}^{2}$ & 3.59 & \pm & 0.88 & 1.75 & \pm & 0.31 & 0.12 & \pm & 0.05 & 0.28 & \pm & 0.13 \\
\hline АК мг/г сух.м. & & НД & & 369.2 & \pm & 9.4 & 613.5 & \pm & 43.5 & 432.4 & \pm & 24.1 \\
\hline $\mathrm{AK}$ г/г $\mathrm{C}$ & 0.60 & \pm & 0.02 & 0.96 & \pm & 0.04 & 1.50 & \pm & 0.14 & 0.84 & \pm & 0.06 \\
\hline
\end{tabular}

НД - нет данных.

динамики видового состава микроводорослей и сравнивали их с сезонными динамиками АК в перифитоне, используя мультивариантный канонический корреляционный анализ (ССА). Цианобактерии вносили самый большой вклад в биомассу перифитона зимой (рис. 1). Диатомовые доминировали (около 100 \%) летом, поздней осенью, в конце зимы начале весны (рис. 1). Биомасса зеленых водорослей достигала максимума и составляла почти 100 \% от общей биомассы в конце весны и в конце лета - начале осени (рис. 1). Се- 

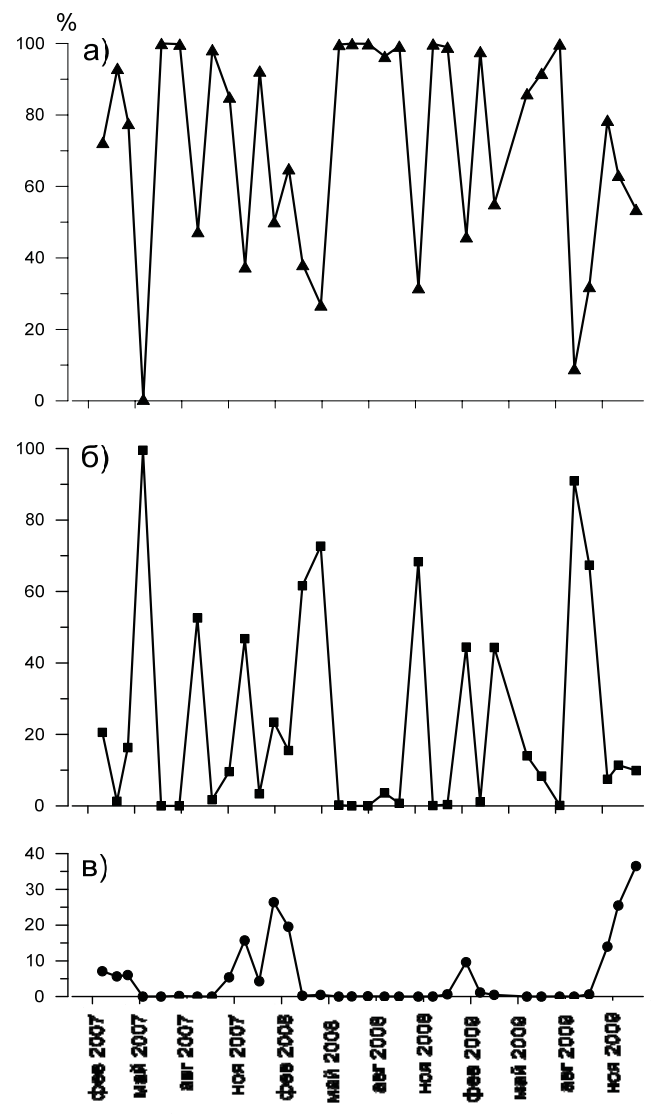

Рис. 1. Сезонная динамика таксономического состава перифитона (\% от общей биомассы) в р. Енисей: a - диатомеи, б - зелёные водоросли, в - цианобактерии

зонные динамики количественно значимых аминокислот даны на рис. 2

Сравнение сезонных динамик с помощью ССА выявило достоверную корреляцию между видами микроводорослей и АК-составом перифитона: как первый, так и второй канонические $R$ (Root 1 , Root 2) были высокими и достоверными (рис. 3,4 ). Наивысший вклад в первый канонический $R$ дает взаимодействие между цианобактериями и Ser, с одной стороны, а также между диатомовыми и $\mathrm{Tyr}-\mathrm{c}$ другой (рис. 4). Действительно, при увеличении доли цианобактерий и диатомовых в перифитоне возрастает процентное содержание Ser и Tyr соответственно (рис. 1 и 2). Взаимодействия между диатомовыми и Glu, а также между зелеными и Phe главным образом дают вклад во второй канонический $R$ (рис. 4). Рост биомассы этих отделов водорослей и содержания соответствующих АК в перифитоне также происходит одновременно (рис. 1 и 2).

Шестнадцать АК, среди которых было 9 незаменимых AK- Lys, His, Arg, Thr, Val, Met, Ile, Leu, Phe, были определены в четырех доминирующих группах зообентоса - гаммарусе и в личинках ручейников, хирономид и поденок (табл. 3). Уровни Thr, Ser, Cys, Met и Arg существенно не различались между видами согласно ANOVA (Fisher LSD post-hoc). Личинки хирономид имели уровни Asp, Phe и Lys существенно выше, чем другие виды, но более низкий уровень Ala (табл. 3). Личинки 

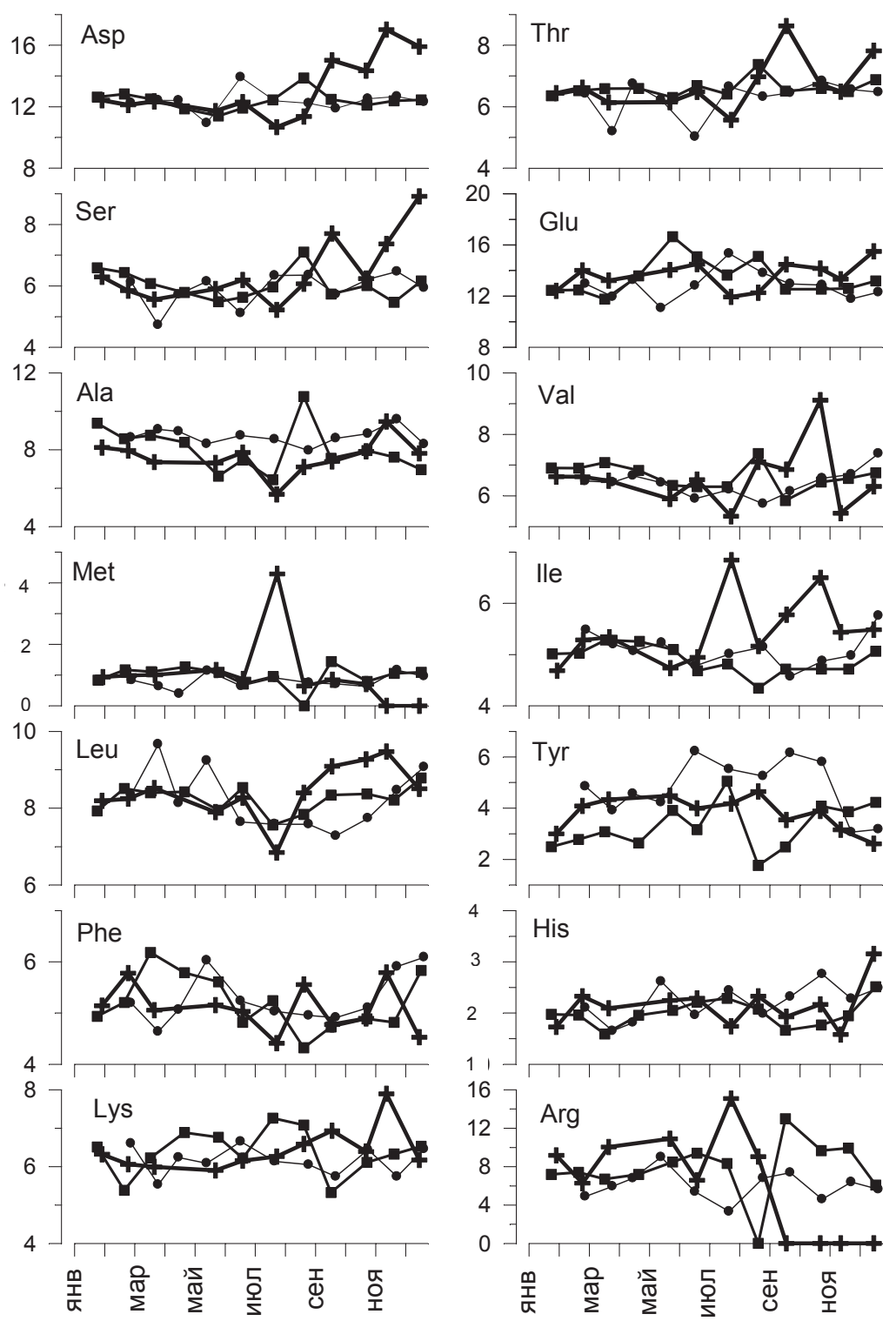

Рис. 2. Сезонная динамика процентных уровней аминокислот (\% от суммы) в фитоперифитоне р. Енисей: кружки - 2007; квадратики - 2008; крестики - 2009

поденок имели наивысший уровень Ala и наименьшие уровни Asp и Phe (табл. 3). Другие виды зообентоса были сравнительно немногочисленны в пробах, и поэтому не имелось достаточного количества данных для анализа сезонных динамик их АК-состава.

Важные индикаторы пищевой ценности зообентоса для рыб, концентрация Met и Lys, а также сумма процентного содержания НАК показаны на рис. 5. Все виды имеют примерно одинаковую пищевую ценность относительно Met. Концентрация Lys в биомассе личинок хирономид была существенно выше, чем в личинках поденок. Уровень незаменимых аминокислот в личинках ручейников и хирономид был до- 

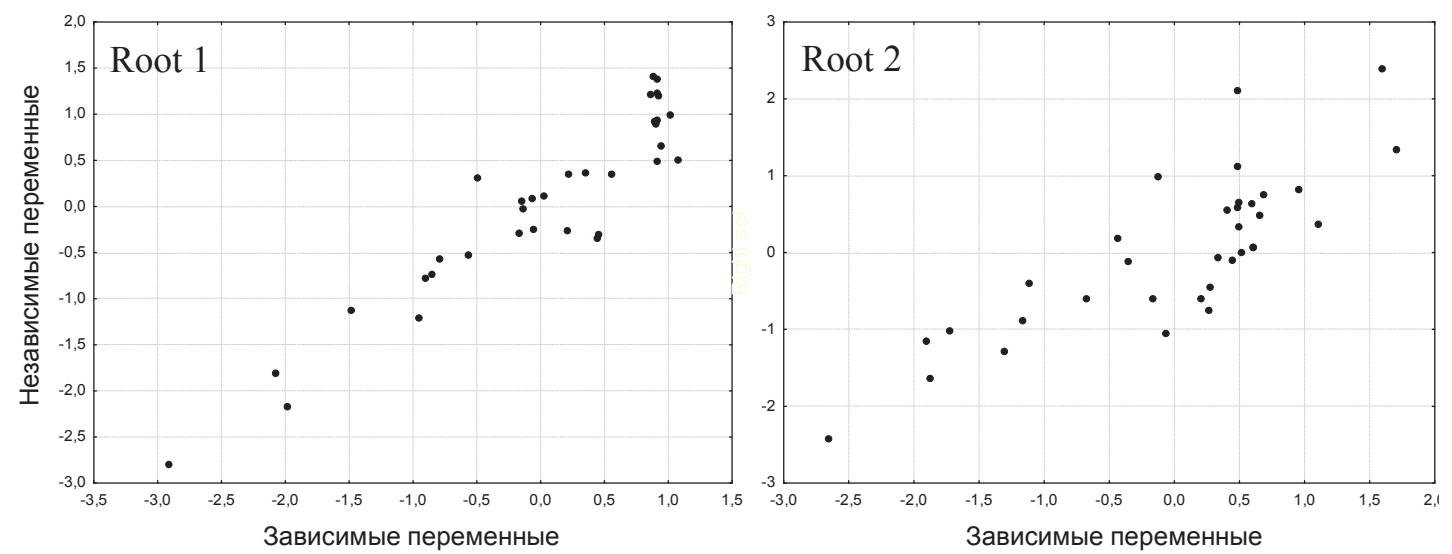

Рис. 3. Диаграммы корреляции между двумя наборами логарифмированных канонических переменных первого и второго канонических корней: доминирующие виды микроводорослей - цианобактерии, диатомовые, зеленые (независимые переменные) против аминокислотного состава фитоперифитона (зависимые переменные) в р. Енисей (2007-2009)

Корень 1
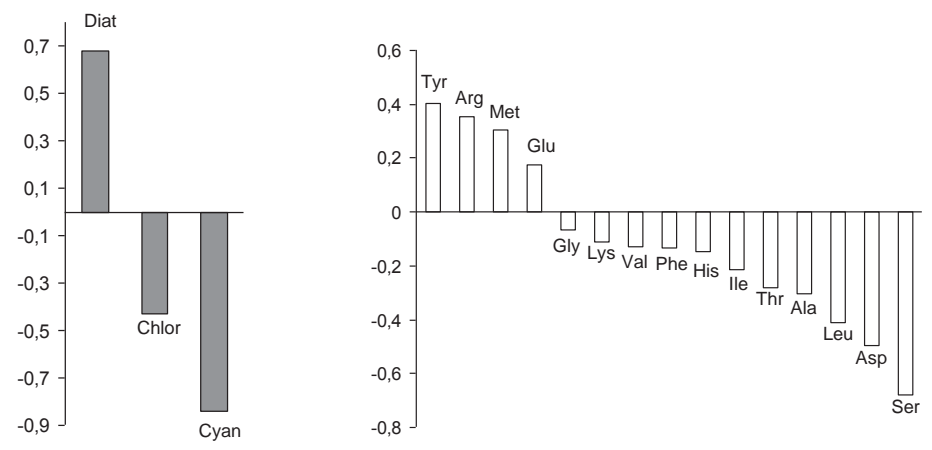

Корень 2
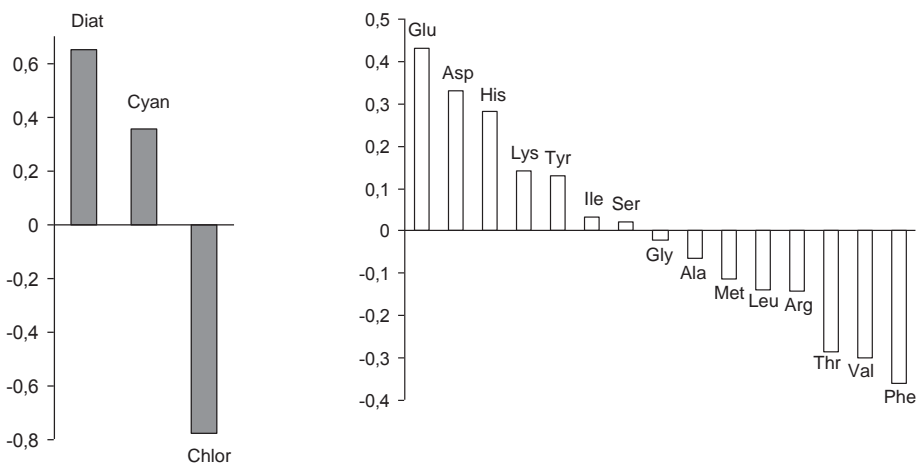

Рис. 4. Значимость факторов в каноническом корреляционном анализе видового и аминокислотного состава фитоперифитона р. Енисей, февраль 2007 - апрель 2010 
Таблица 3. Результаты ANOVA относительного содержания ( \% от суммы) аминокислот (среднее $\pm \mathrm{SE}$ ) в четырех таксонах зообентоса в р. Енисей в окрестностях г. Красноярска, февраль 2007 - апрель 2010: $F$ - тест Фишера и его значимость, $p$; средние, помеченные одинаковой буквой, достоверно не отличаются при $p<0.05$ после LSD post-hoc теста Фишера. НАК выделены жирным шрифтом

\begin{tabular}{ccccccccccccccc}
\hline & \multicolumn{3}{c}{ Gammaridea } & \multicolumn{2}{c}{ Trichoptera } & \multicolumn{2}{c}{ Chironomidae } & \multicolumn{2}{c}{ Ephemeroptera } & $F$ & $p$ \\
\hline Leu & $7.94^{\mathrm{ab}}$ & \pm & 0.15 & $8.00^{\mathrm{a}}$ & \pm & 0.18 & $7.41^{\mathrm{cb}}$ & \pm & 0.21 & $7.55^{\mathrm{ac}}$ & \pm & 0.43 & 1.9 & $>0.05$ \\
Arg & $6.36^{\mathrm{a}}$ & \pm & 0.77 & $8.37^{\mathrm{a}}$ & \pm & 0.92 & $7.23^{\mathrm{a}}$ & \pm & 1.05 & $8.83^{\mathrm{a}}$ & \pm & 0.17 & 1.1 & $>0.05$ \\
Val & $5.59^{\mathrm{ab}}$ & \pm & 0.11 & $6.37^{\mathrm{c}}$ & \pm & 0.13 & $5.43^{\mathrm{a}}$ & \pm & 0.15 & $6.21^{\mathrm{bc}}$ & \pm & 0.31 & 9.9 & $<0.001$ \\
Thr & $5.91^{\mathrm{a}}$ & \pm & 0.17 & $6.07^{\mathrm{a}}$ & \pm & 0.20 & $5.94^{\mathrm{a}}$ & \pm & 0.23 & $5.70^{\mathrm{a}}$ & \pm & 0.47 & 0.2 & $>0.05$ \\
Lys & $7.19^{\mathrm{a}}$ & \pm & 0.18 & $7.18^{\mathrm{a}}$ & \pm & 0.22 & $8.17^{\mathrm{b}}$ & \pm & 0.25 & $6.61^{\mathrm{a}}$ & \pm & 0.51 & 4.7 & $<0.01$ \\
Phe & $5.19^{\mathrm{a}}$ & \pm & 0.13 & $5.07^{\mathrm{a}}$ & \pm & 0.16 & $5.64^{\mathrm{b}}$ & \pm & 0.18 & $3.94^{\mathrm{c}}$ & \pm & 0.37 & 6.2 & $<0.001$ \\
Ile & $4.55^{\mathrm{a}}$ & \pm & 0.07 & $5.00^{\mathrm{b}}$ & \pm & 0.08 & $4.99^{\mathrm{b}}$ & \pm & 0.10 & $4.42^{\mathrm{a}}$ & \pm & 0.20 & 8.5 & $<0.001$ \\
His & $3.24^{\mathrm{a}}$ & \pm & 0.08 & $3.52^{\mathrm{b}}$ & \pm & 0.10 & $3.39^{\mathrm{ab}}$ & \pm & 0.12 & $3.39^{\mathrm{ab}}$ & \pm & 0.24 & 1.5 & $>0.05$ \\
Met & $0.27^{\mathrm{a}}$ & \pm & 0.20 & $0.29^{\mathrm{a}}$ & \pm & 0.24 & $0.66^{\mathrm{a}}$ & \pm & 0.27 & $0.23^{\mathrm{a}}$ & \pm & 0.55 & 0.5 & $>0.05$ \\
Glu & $14.51^{\mathrm{a}}$ & \pm & 0.23 & $12.99^{\mathrm{b}}$ & \pm & 0.28 & $14.59^{\mathrm{a}}$ & \pm & 0.32 & $12.57^{\mathrm{b}}$ & \pm & 0.66 & 8.6 & $<0.001$ \\
Asp & $10.73^{\mathrm{a}}$ & \pm & 0.20 & $11.18^{\mathrm{a}}$ & \pm & 0.25 & $12.82^{\mathrm{b}}$ & \pm & 0.28 & $9.06^{\mathrm{c}}$ & \pm & 0.58 & 17.4 & $<0.001$ \\
Ala & $7.34^{\mathrm{a}}$ & \pm & 0.20 & $6.59^{\mathrm{b}}$ & \pm & 0.25 & $5.57^{\mathrm{c}}$ & \pm & 0.28 & $9.20^{\mathrm{d}}$ & \pm & 0.58 & 14.7 & $<0.001$ \\
Gly & $5.82^{\mathrm{a}}$ & \pm & 0.09 & $5.47^{\mathrm{b}}$ & \pm & 0.11 & $4.88^{\mathrm{c}}$ & \pm & 0.13 & $5.20^{\mathrm{bc}}$ & \pm & 0.26 & 12.0 & $<0.001$ \\
Ser & $5.15^{\mathrm{a}}$ & \pm & 0.11 & $5.16^{\mathrm{a}}$ & \pm & 0.13 & $4.79^{\mathrm{a}}$ & \pm & 0.15 & $5.27^{\mathrm{a}}$ & \pm & 0.31 & 1.5 & $>0.05$ \\
Tyr & $10.08^{\mathrm{a}}$ & \pm & 0.34 & $8.58^{\mathrm{b}}$ & \pm & 0.41 & $8.33^{\mathrm{b}}$ & \pm & 0.47 & $11.64^{\mathrm{a}}$ & \pm & 0.96 & 6.2 & $<0.001$ \\
Cys & $0.12^{\mathrm{a}}$ & \pm & 0.04 & $0.16^{\mathrm{a}}$ & \pm & 0.05 & $0.13^{\mathrm{a}}$ & \pm & 0.06 & $0.17^{\mathrm{a}}$ & \pm & 0.13 & 0.2 & $>0.05$ \\
\hline
\end{tabular}

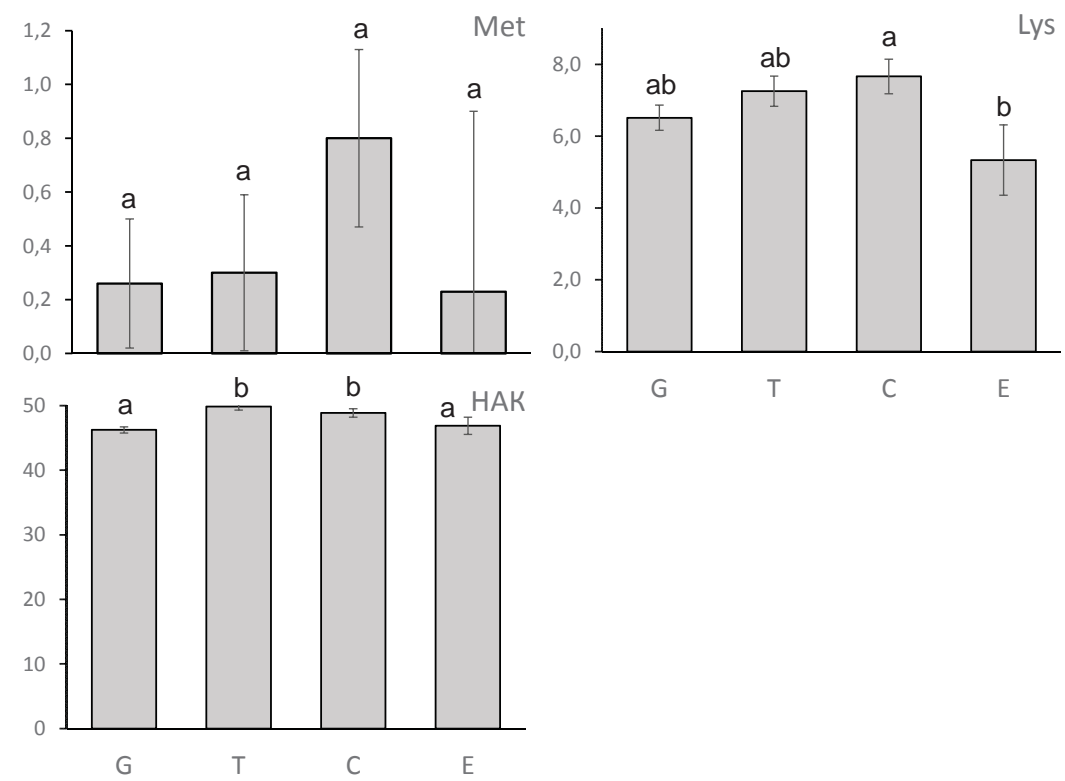

Рис. 5. Диаграммы сравнения концентраций (мг/г с.м.) двух незаменимых аминокислот и суммы незаменимых аминокислот (НАК, \% от общего) в таксонах зообентоса ( $\mathrm{G}$ - гаммарусы, T - личинки ручейников, С - личинки хирономид, Е - личинки поденок) р. Енисей, февраль 2007 - апрель 2010 , полученные с помощью ANOVA. Средние, помеченные одинаковой буквой, достоверно не отличаются 
Перифитон и зообентос

\section{Корень 1}
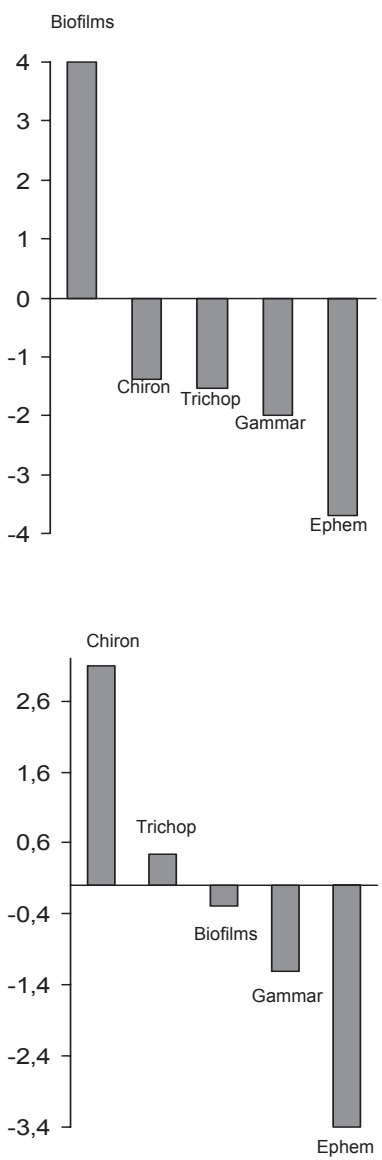

Корень 2
Аминокислоты
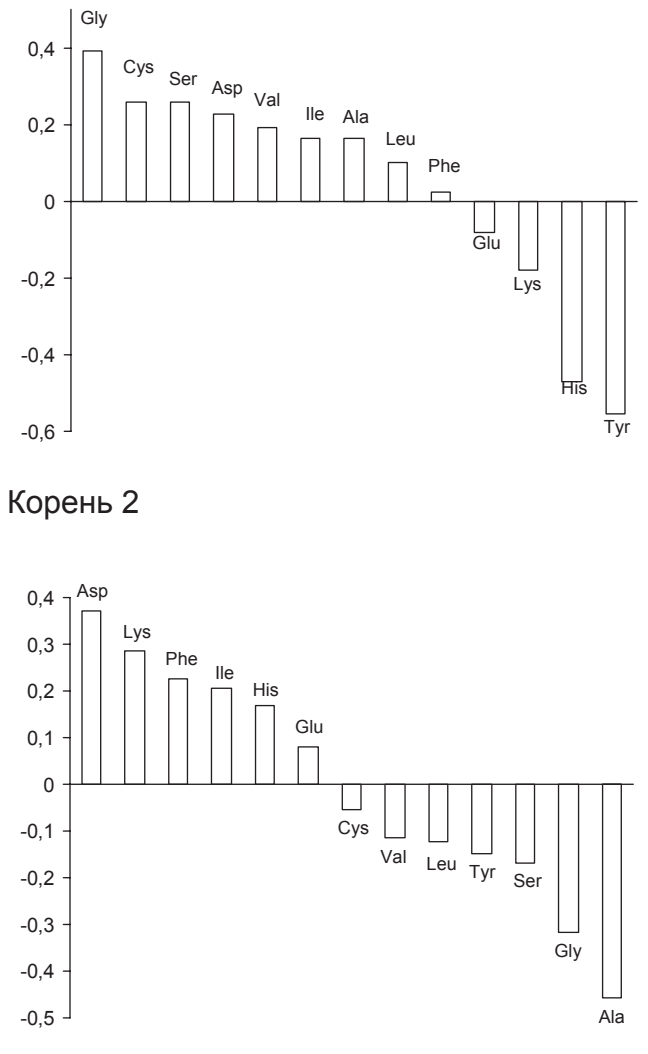

Рис. 6. Значимость факторов в мультивариантном дискриминантном анализе аминокислотных составов перифитона и доминирующих бентосных животных р. Енисей, февраль 2007 - апрель 2010

стоверно выше, чем в личинках поденок и в гаммарусе (рис. 5).

Дискриминантный анализ выявил существенные различия в составе АК между группами изучаемых организмов. Корень 1 наилучшим образом демонстрировал эти различия между перифитоном и всеми животными (рис. 6). Наивысший вклад в первую дискриминантную функцию (Root 1) давали Tyr и His, с одной стороны, и Gly - c другой. Ala и Asp лучше других AК дискриминировали между группами организмов в Root 2 (рис. 6).

\section{Обсуждение результатов}

До сих пор знания об АК-составе перифитонных микроводорослей складывались на основе единичных исследований лабораторных культур морских микроводорослей (Khatoon et al., 2009), водорослевых сообществ, развивающихся в созданных в лаборатории «водотоках» (Steinman and McIntire, 1987), а также эпилитных биопленок из пересыхающего ручья (Ylla et al., 2011). Мы дополнили эти данные результатами своего исследования АК-состава природного перифитона крупной сибирской реки и рассмотрели роль 
АК-состава микроводорослей в изменении качества пищи для зообентоса и рыб. Мы считаем, что состав и содержание аминокислот в перифитоне определяется главным образом микроводорослями и цианобактериями, поскольку перифитон на исследуемом участке p. Енисей в исследуемый период преимущественно состоял из зеленых и диатомовых микроводорослей и цианобактерий, тогда как другие бактерии и мелкие инфузории составляли незначительную часть. Это наблюдение полностью согласуется с данными наших коллег (Sushchik et al., 2007; 2010).

\section{Перифитон: таксономический и АК состав}

Сезонные сукцессии перифитонного сообщества, наблюдаемые в нашем исследовании (рис. 1), были подобны сукцессиям, происходящим в течение ряда лет (2003-2010) на этом участке р. Енисей (Sushchik et al., 2007; 2010; Kolmakov et al., 2008). Три различные совокупности видов микроводорослей развивались в перифитоном сообществе в течение вегетационного сезона: 1) зеленые с диатомовыми микроводорослями в начале вегетационного сезона, 2) преимущественное доминирование (около 100 \%) диатомовых летом, 3) цианобактерии совместно с диатомовыми поздней осенью и зимой. Невозможно было разделить различные таксоны в перифитоне. Поэтому мы сравнили сезонные динамики таксономического состава эпилитных микрофототрофов с сезонными динамиками аминокислот в перифитоне (рис. 1, 2). Мы обнаружили статистически достоверную корреляцию между цианобактериями и Ser, с одной стороны, и между диатомовыми и Tyr с другой, а также между диатомовыми и Glu и между зелеными и Phe (рис. 4).

Таким образом, АК-состав перифитона на исследуемом участке р. Енисей опреде- лялся видовым составом микроводорослей и цианобактерий и, следовательно, изменялся в зависимости от сезонных сукцессий микрофототрофов. К тому же, как было обнаружено в работе Anishchenko et al. (2010), содержание тяжелых металлов в речном перифитоне также частично зависело от видового состава микроводорослей.

В основном представленные данные АКсостава перифитона р. Енисей (табл. 1) существенно не отличаются от данных, полученных для перифитона лабораторного канала (Steinman and McIntire, 1987) и пересыхающего ручья (Ylla et al., 2011). Содержание Glu, Thr, Met, Leu и His в перифитоне лабораторного канала (Steinman and McIntire, 1987) и таковом р. Енисей было на одном уровне. Практически одинаковыми были уровни Ser, Ala, Val, Met и Ile в перифитоне ручья (Ylla et al., 2011) и перифитоне р. Енисей. Однако уровни Asp, Glu и Lys были существенно выше, a His и Arg - ниже в перифитоне р. Енисей, чем в таковом из пересыхающего ручья (Ylla et al., 2011).

Средний уровень НАК в перифитоне p. Енисей был ниже, чем в перифитоне ручья (Ylla et al., 2011), но выше, чем в перифитоне, взятом из лабораторного канала (Steinman and McIntire, 1987) - 47.8, 59.9 и $39.0 \%$ соответственно.

АК-состав перифитона из р. Енисей имел много общего с АК-составом лабораторных культур зеленой микроводоросли Scenedesmus quadricauda Turp., цианобактерии Synechococcus sp. (Ahlgren and Hyenstrand, 2003) и морских диатомовых Amphora и Navicula, выращенных на твердом субстрате (Khatoon et al., 2009). Уровни Thr, Ala, Val, Cys, $\mathrm{Ile}$, Phe и Ніs в изучаемом перифитоне и лабораторных культурах двух видов, Scenedesmus и Synechococcus sp. (Ahlgren and Hyenstrand, 2003), были практически одинаковы. Не об- 
наружено существенных различий в уровнях Thr, Ser, Glu, Gly, Ala, Phe изучаемого перифитона и диатомовой Navicula из морского перифитона (Khatoon et al., 2009). Уровни Thr в речном перифитоне и морской диатомовой водоросли Amphora (Khatoon et al., 2009) были равны. Выраженное сходство уровней АК перифитона р. Енисей, где доминировали диатомовые на протяжении всего периода исследования, и морских диатомовых Navicula и Amphora является еще одним косвенным подтверждением нашего предположения о незначительном вкладе гетеротрофных бактерий и инфузорий в АК-состав перефитонного сообщества. Уровень Asp, Val, Leu в изучаемом перифитоне был выше, а уровни Cys, Met, Tyr, Lys, Arg - ниже, чем в обоих видах морских диатомовых Amphora и Navicula (Khatoon et al., 2009). Уровень Met в перифитоне р. Енисей был ниже, чем в лабораторных культурах Scenedesmus и Synechococcus sp. (Ahlgren and Hyenstrand, 2003) и видах морских диатомовых Amphora и Navicula (Khatoon et al., 2009). Уровень Lys в Scenedesmus и в морских диатомовых Amphora и Navicula был выше, а в Synechococcus sp. ниже, чем в исследуемом речном перифитоне. Однако уровень НАК в перифитоне р. Енисей был таким же, как в Amphora (Khatoon et al., 2009), Scenedesmus и Synechococcus sp. (Ahlgren and Hyenstrand, 2003), и составлял в среднем около $48 \%$.

\section{Вопрос о лимитировании}

Известно, что различия в содержании биогенных элементов у различных видов гетеротрофных организмов ниже, чем у автотрофных (Sterner and Schulz, 1998). Как правило, беспозвоночные стремятся регулировать свой АК-состав гомеостатически, что обеспечивает постоянство уровня АК в организмах консументов, несмотря на изменения доступности АК в пище. Однако это увеличивает риск лимитирования беспозвоночных недостатком отдельных аминокислот в пище (перифитоне). Поскольку перифитон - источник вещества и энергии для бентосных животных, включая макрозообентос, а тот, в свою очередь, служит пищей для личинок многих рыб, возникает важный вопрос: могут ли выявленные видоспецифичные особенности профиля АК потенциально быть лимитирующим фактором для роста и развития зообентоса и рыб? Согласно распространенному подходу ценность пищи считается высокой, если ее АКсостав близок к АК-составу потребляющих ee животных (Brown et al., 1997; Conceição et al., 2003). Процентный уровень большинства незаменимых АК в перифитоне был выше (или равен), чем в зообентосе (табл. 1). Однако средние процентные уровни незаменимых AK, таких как Lys и His в перифитоне, были существенно ниже, чем в зообентосе. ССА (рис. 3, 4) выявил достоверную корреляцию между видами и АК-составом перифитона. Хотя сезонное изменение видового состава перифитона не сопровождалось заметными изменениями в продукции НАК, более низкое процентное содержание Lys и His в перифитоне по сравнению с зообентосом могло приводить к лимитированию бентосных беспозвоночных этими незаменимыми АК. Очевидно, чтобы обеспечить достаточный уровень Нis и Lys, зообентосу необходимо селективно потреблять из перифитона виды водорослей со сравнительно более высоким содержанием этих НАК.

Наряду с качественным составом абсолютное количество АК в перифитоне является важным фактором в удовлетворении пищевых потребностей консументов. Здесь наши количественные данные показывают две противоположных тенденции. Запас аминокислот на единицу площади речного дна в перифитоне был выше, чем таковой в доми- 
нирующих бентосных животных, тогда как содержание АК на единицу массы углерода было выше в зообентосе, чем в перифитоне (табл. 2). Поэтому в дальнейших исследованиях необходимо будет сравнить продукцию АК перифитона с потребностями зообентоса.

\section{AK зообентоса}

Мы не нашли данных по содержанию АК в организмах речного зообентоса, чтобы сравнить их с полученными АК-профилями зообентоса р. Енисей. Поэтому для сравнения мы использовали соответствующие данные морского и пресноводного зоопланктона. Таким образом, мы сравнили наши данные с данными по содержанию АК в Daphnia pulicaria (Cladocera), Cyclops abyssorum (Copepoda: Cyclopoida) и Diaptomus cyaneus (Copepoda: Calanoida) из олиготрофного альпийского озера (Ventura and Catalan, 2010), а также морских копепод Euterpina (Harpacticoida) (Guisande et al., 1999) и обнаружили много общего. D. pulicaria (Ventura and Catalan, 2010) имела те же уровни Val, Ala, Glu и Phe, как и исследуемые личинки Trichoptera, а уровень Gly такой же, как личинки Ephemeroptera. У C. abyssorum были такие же уровни Asp, Ile, Leu и Lys, как у личинок Ephemeroptera. D. cyaneus имел уровень Arg такой же, как в Gammaridea, и уровень Gly, как в Ephemeroptera.

Уровни Ser во всех изученных группах зообентоса в р. Енисей и приведенных выше видах пресноводного зоопланктона (Ventura and Catalan, 2010) были практически равны. Уровни Gly, Lys и Leu в морских копеподах (Guisande et al., 1999) были близки к таковым в зообентосе p. Енисей. Уровни Рhе в личинках Ephemeroptera, Ile в личинках Trichoptera, Ser личинках Chironomidae, Val в Gammaridea были равны таковым в морских копеподах (Guisande et al., 1999).
Однако наряду со сходством в уровнях индивидуальных АК между разными видами беспозвоночных наблюдались и различия. Уровни Asp, His, Thr, Tyr и Phe во всех изученных видах зообентоса из р. Енисей были выше, а уровень Gly - немного ниже, чем в морских копеподах (Guisande et al., 1999). Особенно значительные различия были между изучаемым зообентосом и пресноводным зоопланктоном в уровнях His и Tyr (Ventura and Catalan, 2010). Уровни Нis и Tуг во всех изученных видах зообентоса из р. Енисей были существенно выше, а уровень Met - cyщественно ниже, чем во всех видах пресноводного зоопланктона (Ventura and Catalan, 2010).

Многие исследователи считают АКсостав взрослых водных беспозвоночных неизменным (Cowey and Corner, 1963; Cowgill et al., 1986; Guisande et al., 2000). Однако существует ряд работ, подтверждающих, что репродуктивные, половые и онтогенетические изменения влияют на АК-состав беспозвоночных (Helland et al., 2003; Brucet et al., 2005). Известно также, что межвидовые различия больше, чем внутривидовые, что также подтверждает отсутствие строгого гомеостаза в пресноводном ракообразном зоопланктоне (Ventura and Catalan, 2010). Более того, предлагается использовать АК-состав видов как индикатор трофической ниши и адаптации видов к абиотическим факторам (Guisande, 2006). Наши данные также выявили определенные различия АК-состава у исследуемых видов зообентоса (табл. 3). Хотя уровни некоторых АK (Thr, Ser, Cys, Met и Arg) были одинаковы у различных видов, в уровнях других АК наблюдались значительные различия между видами. Личинки хирономид содержали значительно более высокие уровни Asp, Phe и Lys, но самый низкий уровень Ala, чем другие виды. Напротив, личинки поде- 
нок имели наивысший уровень Ala, но самый низкий уровень Asp и Рhe. Вероятно, различия АК-состава у разных видов зообентоса были связаны с питанием этих видов разными группами водорослей, как это показано в pаботе Sushchik et al. (2003).

Анализ содержания АК в зообентосе важен для определения пищевой ценности различных видов бентосных беспозвоночных для питания рыб. Во многих исследованиях успех разведения беспозвоночных и рыб в аквакультуре связывается с содержанием НАК в пище, особенно с концентрациями Lys и Met (Conceicao et al., 2003; Li et al., 2009; Helland et al., 2010). В изученном зообентосе средний уровень Lys (7.4%) (табл. 1) был практически таким же, как опубликованный для различных видов водных беспозвоночных - пресноводной креветки Macrobrachium rosenbergii (7.8 \%) (Tidwell et al., 1998), морских копепод Euterpina (7.4 \%) (Guisande et al., 1999), мидии Mytilus coruscus (7.7 \%) (Li et al., 2010) и каланоидной копеподы Diaptomus cyaneus (7.5 \%) (Ventura and Catalan, 2010). Напротив, уровень Met в зообентосе р. Енисей был одинаков у всех видов (в среднем 0.4 \%), но существенно ниже опубликованных данных, которые, как правило, колебались между 1.7-3.9 \% (Tidwell et al., 1998; Aragao et al., 2004; Ventura and Catalan, 2010), но иногда достигали $7.3 \%$ (Li et al., 2010).

С помощью дискриминантного анализа (рис. 6) и анализа ANOVA, проведенного для уровней АК в пробах зообентоса (табл. 3), были получены доказательства того, что доминирующие виды зообентоса имеют различный АК-состав. Возникает вопрос: как отражаются различия между АК-профилями исследованных бентосных животных на пищевой ценности зообентоса как пищи для рыб? Как обнаружено, не существует различий в пищевой ценности всех видов зообенто- са относительно Met. Однако нами обнаружено, что в личинках хирономид концентрация Lys существенно выше, чем в личинках поденок и гаммарусах (табл. 4). Процентный уровень НАК в личинках ручейников и хирономид был существенно выше, чем в личинках поденок и гаммарусах. Таким образом, можно предположить, что личинки ручейников и хирономид являются более ценной пищей для рыб по сравнению с личинками поденок и гаммарусами.

Данные по различной пищевой ценности видов зообентоса могут иметь экологическое значение для речных экосистем. В настоящее время на исследуемом участке p. Енисей наблюдается инвазия гаммаруса, E. viridis из оз. Байкал. Гаммарусы вытесняют личинок ручейников и хирономид, доминировавших в р. Енисей до инвазии (Gladyshev and Moskvicheva, 2002). Согласно нашим данным, по уровню НАК пищевая ценность гаммаруса для рыб ниже, чем личинок ручейников и хирономид (рис. 4). Высокий уровень НАК в пище, как известно, необходим для роста рыб (Peres and OlivaTeles, 2006). Хотя биомасса зообентоса не изменилась вследствие инвазии гаммаруса, пищевая ценность зообентоса по уровню НАК стала ниже.

\section{Заключение}

Нами было установлено, что профили незаменимых аминокислот в перифитоне изменялись в связи с сукцессией видов эпилитных микроводорослей. В целом, существует несбалансированность процентного состава двух АК (лизина и гистидина) между перифитоном и зообентосом. Более того, зообентос имеет значительно более высокое содержание АК на единицу углерода, чем микроводоросли или цианобактерии. Гаммарус $E$. viridis, недавно вселившийся в изучаемый 
участок реки, обладал значительно более низкой пищевой ценностью, чем аборигенные таксоны. Таким образом, уровень НАК, определяющий пищевую ценность нижнего звена трофической цепи речной экосистемы, необходимо учитывать как имеющий потенциальное значение для высшего трофического уровня - рыб.

Работа выполнена в рамках Государственного задания Министерства образования и науки Российской Федерации Сибирскому федеральному университету на 2014-2016 годы (проект № 3079 «Эколого-биохимические закономерности переноса вещества и энергии в трофических сетях водных экосистем»).

\section{Список литературы}

1. Acharya K., Kyle M., Elser J.J. (2004) Effects of stoichiometric dietary mixing on Daphnia growth and reproduction. Oecologia 138: 333-340.

2. Anderson T.R., Boersma M., Raubenheimer D. (2004) Stoichiometry: linking elements to biochemicals. Ecology 85: 1193-1202.

3. Anishchenko O.V., Gladyshev M.I., Kravchuk E.S., Ivanova E.A., Gribovskaya I.V., Sushchik N.N. (2010) Seasonal variations of metal concentrations in periphyton and taxonomic composition of the algal community at a Yenisei River littoral site. Central European Journal of Biology 5: 125-134.

4. Ahlgren G., Gustafsson I.B., Boberg M. (1992) Fatty acid content and chemical composition of freshwater microalgae. Journal of Phycology 28: 37-50.

5. Ahlgren G., Hyenstrand P. (2003) Nitrogen limitation effects of different nitrogen sources on nutritional quality of two freshwater organisms, Scenedesmus quadricauda (Chlorophyceae) and Synechococcus sp. (Cyanophyceae). Journal of Phycology 39: 906-917.

6. Aragão C., Conceição L.E.C., Dinis M.T., Fyhn H.-J. (2004) Amino acid pools of rotifers and Artemia under different conditions: nutritional implications for fish larvae. Aquaculture 234: 429-445.

7. Boersma M., Schops C., McCauley E. (2001) Nutritional quality of seston for the freshwater herbivore Daphnia galeata $\times$ hyalina: biochemical versus mineral limitation. Oecologia 129: 342348.

8. Brown M.R., Jeffrey S.W., Volkman J.K., Dunstan G.A. (1997) Nutritional properties of microalgae for mariculture. Aquaculture 151: 315-331.

9. Brett M.T., Muller-Navarra D.C. (1997) The role of highly unsaturated fatty acids in aquatic foodweb processes. Freshwater Biology 38: 483-499.

10. Brucet S., Boix D., Lopez-Flores R., Badosa A., Quintana, X.D. (2005) Ontogenetic changes of amino acid composition in planktonic crustacean species. Marine Biology 148: 131-139.

11. Campbell R.C. (1967) Statistics for biologists. Cambridge: University Press .

12. Conceição L.E., Grasdalenb C.H., Ronnestad I. (2003) Amino acid requirements of fish larvae and post-larvae: new tools and recent findings. Aquaculture 227: 221-232.

13. Cowey C.B., Corner E.D.S. (1963) On the nutrition and metabolism of zooplankton II. The relationship between the marine copepod Calanus helgolandicus and particulate material in playmouth sea water, in terms of amino acid composition. Journal of the Marine Biological Association of the United Kingdom 43: 495-511. 
14. Cowgill U.M., Emmel H.W., Hopkins D.L., Takahashi I.T., Parker W.M. (1986) Variation in chemical composition, reproductive success and body weight of Daphnia magna in relation to diet. Internationale Revue der Gesamten Hydrobiologie und Hydrographie 71: 79-99.

15. Cross W.F., Benstead J.P., Frost P.C., Thomas S.A. (2005) Ecological stoichiometry in freshwater benthic systems: recent progress and perspectives. Freshwater Biology 50: 1895-1912.

16. Forster I., Ogata H.Y. (1998) Lysine requirement of juvenile Japanese flounder Paralichthys olivaceus and juvenile red sea bream Pagrus major. Aquaculture 161: 131-142.

17. Fox J.M., Lawrence A.L., Li-Chan E. (1995) Dietary requirement for lysine by juvenile Penaeus vannamei using intact and free amino acid sources. Aquaculture 131: 279 - 290.

18. Fuller R.L., Bucher J.B. (1991) A portable chamber for measuring algal primary production in streams. Hydrobiologia 209: 155-159.

19. Gladyshev M. I., Moskvicheva A. V. (2002) Baikal invaders have become dominant in the upper Yenisei benthofauna. Doklady Biological Sciences 383: 138-140.

20. Gladyshev M.I., Sushchik N.N., Kolmakova A.A., Kalachova G.S., Kravchuk E.S., Ivanova E.A., Makhutova O.N. (2007) Seasonal correlations of elemental and $\omega 3$ PUFA composition of seston and dominant phytoplankton species in a eutrophic Siberian Reservoir. Aquatic Ecology 41: 9-23.

21. Gladyshev M.I., Sushchik N.N., Kalachova G.S., Makhutova O.N. (2012) Stable isotope composition of fatty acids in organisms of different trophic levels in the Yenisei River. PLoS ONE 7(3), e34059. doi:10.1371/journal.pone.0034059.

22. Giani A. (1991) Implications of phytoplankton chemical composition for zooplankton production: experimental evidence. Oecologia 87: 409-416.

23. Guisande C., Maneiro I., Riveiro I. (1999) Homeostasis in the essential amino acid composition of the marine copepod Euterpina acutifrons. Limnology and Oceanography 44: 691-696.

24. Guisande C., Riveiro I., Maneiro I. (2000) Comparison among the amino acid composition of females, eggs and food to determine the relative importance of food quantity and food quality to copepod reproduction. Marine Ecology Progress Series 202: 135-142.

25. Guisande C. (2006) Biochemical fingerprints in zooplankton. Limnetica 25: 369-376.

26. Helland S., Nejstgaard J.C., Humlen R., Fyhn H.J., Bamstedt U. (2003) Effects of season and material food on Calanus finmarchicus reproduction, with emphasis on the free amino acids. Marine Biology 142: 1141-1151.

27. Helland S.J., Hatlen B., Grisdale-Helland B. (2010) Energy, protein and amino acid requirements for maintenance and efficiency of utilization for growth of Atlantic salmon post-smolts determined using increasing ration levels. Aquaculture 305: 150-158.

28. Hill W.R., Knight A.W. (1987) Experimental analysis of the grazing interaction between a mayfly and stream algae. Ecology 68: 1955-1965.

29. Hillebrand H., Durselen C.D., Kirschtel D., Pollingher U., Zohary T. (1999) Biovolume calculation for pelagic and benthic microalgae. Journal of Phycology 35: 403-424.

30. Jefers J. (1981) An introduction to system analysis: with ecological application. Moscow: Mir, $252 \mathrm{p}$.

31. Kalachova G.S., Kolmakova A.A., Gladyshev M.I., Kravchuk E.S., Ivanova E.A. (2004) Seasonal dynamics of amino acids in two small Siberian reservoirs dominated by prokaryotic and eukaryotic phytoplankton. Aquatic Ecology 38: 3-15.

$$
-102-
$$


32. Kalachova G.S., Gladyshev M.I., Sushchik N.N., Makhutova O.N. (2011) Water moss as a food item of the zoobenthos in the Yenisei River. Central European Journal of Biology 6(2): 236-245.

33. Kim J-D., Lall S.P. (2000) Amino acid composition of whole body tissue of Atlantic halibut (Hippoglossus hippoglossus), yellowtail flounder (Pleuronectes ferruginea) and Japanese flounder (Paralichthys olivaceus). Aquaculture 187(3-4): 367-373.

34. Khatoon H., Banerjee S., Yusoff F.M., Shariff M. (2009) Evaluation of indigenous marine periphytic Amphora, Navicula and Cymbella grown on substrate as feed supplement in Penaeus monodon postlarval hatchery system. Aquaculture Nutrition 15: 186-193.

35. Kleppel G.S., Burkart C.A., Houchin L. (1998) Nutrition and the regulation of egg production in the calanoid copepod Acartia tonsa. Limnology and Oceanography 43: 1000-1007.

36. Kolmakov V.I., Anishchenko O.V., Ivanova E.A., Gladyshev M.I., Sushchik N.N. (2008) Estimation of periphytic microalgae gross primary production with DCMU-fluorescence method in Yenisei River (Siberia, Russia). Journal of Applied Phycology 20: 289-297.

37. Koch U., Martin-Creuzburg D., Grossart H.P., Straile D. (2011) Single dietary amino acids control resting egg production and affect population growth of a key freshwater herbivore. Oecologia 167: 981-989.

38. Lehninger A.L., Nelson D.L., Cox M.M. (1993) Principles of Biochemistry. New York: Worth Publishers .

39. Li P., Burr G.S., Wen Q., Goff J.B., Murthy H.S., Gatlin D.M. (2009) Dietary sufficiency of sulfur amino acid compounds influences plasma ascorbic acid concentrations and liver peroxidation of juvenile hybrid striped bass (Morone chrysops. M. saxatilis). Aquaculture 287: 414-418.

40. Li G., Li J., Li D. (2010) Seasonal Variation in Nutrient Composition of Mytilus coruscus from China. Journal of Agricultural and Food Chemistry 58: 7831-7837.

41. Martin-Creuzburg D., Wacker A., Von Elert E. (2005) Life history consequences of sterol availability in the aquatic keystone species Daphnia. Oecologia 144: 362-372.

42. Muller-Feuga A. (2000) The role of microalgae in aquaculture: situation and trends. Journal of Applied Phycology 12: 527-534.

43. Muller-Navarra D. (2008) Food web paradigms: the biochemical view on trophic interactions. International Review of Hydrobiology 93(4-5): 489-505.

44. Peres P., Oliva-Teles A. (2006) Effect of the dietary essential to non-essential amino acid ratio on growth, feed utilization and nitrogen metabolism of European sea bass (Dicentrarchus labrax). Aquaculture 256: 395-402.

45. Power M.E., Matthews W.J. (1983) Algae-grazing minnows (Campostoma anomalum) piscivorous bass (Micropterus spp.), and the distribution of attached algae in a small prairie-margin stream. Oecologia 60: 328-332.

46. Ronnestad I., Thorsten A., Finn R.N. (1999) Fish larval nutrition: a review of recent advances in the roles of amino acids. Aquaculture 177: $201-216$.

47. Steinman A.D., McIntire C.D. (1987) Effects of herbivore type and density on chemical composition of algal assemblages in laboratory streams. Journal of the North American Benthological Society 6(3): 189-197.

48. Stelzer R.S., Lamberti G.A. (2002) Ecological stoichiometry in running waters: periphyton chemical composition and snail growth. Ecology 83: 1039-1051. 
49. Sterner R.W., Schulz K.L. (1998) Zooplankton nutrition: recent progress and a reality check. Aquatic Ecology 32: 261-279.

50. Sushchik N.N., Gladyshev M.I., Moskvichova A.V., Makhutova O.N., Kalachova G.S. (2003) Comparison of fatty acid composition in major lipid classes of the dominant benthic invertebrates of the Yenisei River. Comparative Biochemistry and Physiology B 134: 111-122.

51. Sushchik N.N., Gladyshev M.I., Kalachova G.S., Makhutova O.N., Ageev A.V. (2006) Comparison of seasonal dynamics of the essential PUFA contents in benthic invertebrates and grayling Thymallus arcticus in the Yenisei River. Comparative Biochemistry and Physiology B 145: 278-287.

52. Sushchik N.N., Gladyshev M.I., Kravchuk E.S., Ivanova E.A., Ageev A.V., Kalachova G.S. (2007) Seasonal dynamics of long-chain polyunsaturated fatty acids in littoral benthos in the upper Yenisei River. Aquatic Ecology 41:349-365.

53. Sushchik N.N., Gladyshev M.I., Ivanova E.A., Kravchuk E.S. (2010) Seasonal distribution and fatty acid composition of littoral microalgae in the Yenisei River. Journal of Applied Phycology 22: $11-24$.

54. Telang S.A., Pocklington R., Naidu A.S., Romankevich E.A., Gitelson I.I., Gladyshev M.I. (1991) Carbon and mineral transport in major North American, Russian Arctic, and Siberian Rivers: the St Lawrence, the Mackenzie, the Yukon, the Arctic Alaskan Rivers, the Arctic Basin rivers in the Soviet Union, and the Yenisei. In: E.T. Degens, S. Kempe, J.E. Richey (Eds) Biogeochemistry of major world rivers. Chichester: Wiley, p. 75-104.

55. Tidwell J.H., Webster C.D., Coyle S.D., Daniels W.H., D'Abramo L.R. (1998) Fatty acid and amino acid composition of eggs, muscle and midgut glands of freshwater prawns, Macrobrachium rosenbergii (de Man), raised in fertilized ponds, unfertilized ponds or fed prepared diets. Aquaculture Research 29: 37-45.

56. Uehlinger U. (2006) Annual cycle and inter-annual variability of gross primary production and ecosystem respiration in a floodprone river during a 15-year period. Freshwater Biology 51: 938-950.

57. Ventura M., Liboriussen L., Lauridsen T., Sondergaard M., Sondergaard M., Jeppesen E. (2008) Effects of increased temperature and nutrient enrichment on the stoichiometry of primary producers and consumers in temperate shallow lakes. Freshwater Biology 53: 1434-1452.

58. Ventura M., Catalan J. (2010) Variability in amino acid composition of alpine crustacean zooplankton and its relationship with nitrogen-15 fractionation. Journal of Plankton Research 32 (11): 1583-1597.

59. Walton M.J., Cowey C.B., Adron J.W. (1984) The effect of dietary lysine levels on growth and metabolism of rainbow trout (Salmo gairdneri). British Journal of Nutrition 52: 115-122.

60. Wilson R.P., Poe W.E. (1985) Relationship of whole body and egg essential amino acid patterns to amino acid requirement patterns in channel catfish, Ichalurus punctatus. Comparative Biochemistry and Physiology 80B: 385-388.

61. Wilson R.P., Cowey C.B. (1985) Amino acid composition of whole body tissue of rainbow trout and Atlantic salmon. Aquaculture 48, 3-4: 373-37.

62. Ylla I., Sanpera-Calbet I., Munoz I., Romani A.M., Sabater S. (2011) Organic matter characteristics in a Mediterranean stream through amino acid composition: changes driven by intermittency. Aquatic Sciences 73: 523-535 